\title{
'Once there was a learning developer...': the potential of parables to stimulate critique.
}

\author{
Steve Rooney \\ University of Leicester
}

\begin{abstract}
This article builds on a workshop that took place at the Association for Learning Development in Higher Education (ALDinHE) annual conference in April 2019. It explores the role of the parable in provoking and stimulating debate and critical reflection. Beginning with a discussion of the parable as a form, the article then explores how the oft-cited parables that appear in the Gospels according to Mark, Matthew and Luke help to reveal the subversive pedagogical potential of parables. Returning to the terrain of contemporary higher education, it is argued that the parable is an apt form for encouraging education practitioners to explore more deeply and more critically some of the assumptions and practices they encounter in their working lives. All this serves as a prelude to the presentation of a selection of parables, which are accompanied by some guidance to help structure and support engagement. The article 'concludes', at the risk of infuriating readers, with yet another parable.
\end{abstract}

Keywords: Learning development; reflective practice; criticality; creative writing.

\section{Prologue}

'Examples persuade; parables provoke'

John Dominic Crossan (1976, p.104)

Once there was a learning developer who, during a workshop at the 2019 annual conference of the Association for Learning Development in Higher Education, presented the following parable about parables, by the great Franz Kafka: 
Many people complained that the words of the wise were always couched in the form of parables, but were useless in daily life, which is the only sort of life we have. When the wise man says: "Cross over," he doesn't mean that we should cross over to the other side of the street, which is something we might at least be able to do, if it were worth our while; no, he means some fabulous yonder, some place we don't know, some place that doesn't get any closer description from him either and that therefore can't help us. All these parables are really trying to tell us is that the intangible is impossible to grasp and we knew that anyway. But the things we struggle with every day, those are different.

Thereupon someone said: 'Why struggle? If you followed the parables, then you would have become parables yourselves, and thereby free of your daily cares.'

Someone else said: 'I bet that's a parable as well.'

The first person said: 'You have won.'

The second said: 'Yes, but unfortunately only in a parable.'

The first man said: 'No, in reality: in the parable you've lost.'

On Parables (Kafka, 2017 [1922], p.181)

\section{Introduction}

Somewhat daunted by the company I have chosen to keep, here, I would like to share some parables I have been working on. They deal with various aspects of educational practice, features of institutional life, and commonly expressed values and assumptions with which fellow learning developers and other higher education practitioners should, I hope, be familiar. Before getting to the stories themselves, though, I want to discuss some of my original and abiding inspirations (ancient and biblical, modern and secular) for deciding to have a go at writing them in the first place. In doing so, I hope to establish a little more clearly the pedagogical 'work' that parables set out to do.

\section{'Away from here, away from here' (Kafka, 2017 [1922], p.124): where parables tend to take us}

It is not uncommon to encounter 'the parabolic' in books, films, TV shows etc., which point towards social, moral, political or existential themes beyond their immediate fictive context. 
Thompson (n.d.), for instance, describes Chimamanda Ngozi Adiche's 2006 novel, Half of a Yellow Sun, as 'a parable of race, class and politics' in postcolonial Nigeria. Arundhati Roy's Capitalism: A Ghost Story (2015) opens with a gut-wrenching parabolic story concerning the material and spiritual harms wrought by neoliberalism in contemporary India. For the purposes of this article, though, I have in mind a more specific tradition of story-telling; often involving quite short, or 'micro', stories, containing deliberate elements of surprise, strangeness and equivocacy. As Thomas C. Oden (1978) notes in his introduction to The Parables of Kierkegaard, parables of this kind have been deployed throughout the world, and across cultures, for thousands of years. To draw on an example from twentieth-century Europe, Gerhart Fishcher (2008, p.138) describes Bertolt Brecht's parables as seeking to make 'the familiar appear strange', and in doing so to raise 'the question of why things are as they are... [in order to] open up a process of critical thinking'. As James Champion (1981, p.21) observes, Brecht's near contemporary Franz Kafka likewise used parables to produce a 'radical displacement of how things are supposed to go in the order of things.' Walter Benjamin (2008 [1934], pp.83-84), in an essay on Kafka, deploys a parable of his own - one that exemplifies well, I think, how this kind of 'radical displacement' of expectations often plays out. Benjamin's story is set in a 'shabby inn' where a group of acquaintances are playfully discussing 'what each man thought he would wish for if he had a wish to spare.' Things proceed predictably enough: 'One wanted gold, another a son-in-law, a third a new carpenter's bench...' When, however, a 'shabbily dressed' beggar is pressed to speak, he has this to say:

'l'd wish I was a great and powerful king and ruled a large country and was lying asleep one night...when the enemy breached the frontier and horsemen reached the square in front of my palace before dawn and there was no resistance and I, starting up out of sleep, no time even to get dressed, wearing just my shirt, had to take flight and was chased up hill and down dale, through forests and mountains, day and night without let-up, until I had reached this bench in your corner, safe. That is what I would wish.' The others looked at one another in bewilderment. 'But what would such a wish leave you with?' asked one. 'A shirt.' Was the reply.

These kinds of strange, expectation-confounding qualities are likewise frequently to be found in some the most famous and widely-cited parables of all: those attributed to Jesus of Nazareth, and found in the Gospels of Mark, Matthew and Luke ('the Synoptic Gospels' 
as they are known collectively). It was re-encountering these, and some of the scholarship concerning them, that first ignited my own curiosity about parables. I would like, then, to spend a little time clarifying what these stories reveal about the pedagogical purpose and workings of the parable.

\section{'But alas for you who are rich...' (Luke, 6: 24-25, in Hart, 2017, p. 118): The Gospel parables' subversive pedagogy}

'It is interesting, if not surprising, to watch white New Testament scholars explain away the real theological significance of Jesus' teachings on the kingdom and the poor.'

James H. Cone (2018 [1970], p.122)

There persists, it seems, a popular perception that the parables that appear in the Synoptic Gospels are intended primarily as 'religious' (in the modern, and somewhat impoverished, sense of that term) stories relaying clear moral-religious messages (Rollins, 2006). This is, I suppose, symptomatic of a broader, and similarly anachronistic, tendency to view the Bible itself as a 'book' containing consistent, clear-cut, moral-religious instruction for the pious. But the Bible is, of course, nothing of the sort. Indeed, a regular theme to emerge from the pages of this dizzyingly diverse, multi-genre compilation of ancient Hebrew and Greek texts is, as Terry Eagleton (2009: p.8) writes, 'God's endless... struggle with organized religion' (as well as, we should add, with pharaohs, kings and emperors). In the Gospels of the Christian canon, these are struggles said to find their ultimate expression in the person, life and teachings of an itinerant Galilean artisan and popular prophet, executed as a result of the combined actions of Jerusalem's aristocratic high-priestly ruling class and the colonial power under whose control and supervision they ruled (Carter, 2006). Even by the often extravagantly sadistic standards of the Roman Empire, crucifixion was a particularly horrific form of public state killing - reserved for those classed as 'non-persons', deployed as punishment for political offences, and designed explicitly 'to terrorize subject peoples into submission.' (Horsley, 2013, p.156). And keeping in mind this broader narrative context of the Gospels - of Jesus incurring the ultimate punitive sanction of the repressive imperial state apparatus - is important in helping us appreciate the critical-pedagogical role played by the stories he himself tells (Herzog, 1994; Schottroff, 2009). 
Broadly speaking, these stories served to provoke reflection on the nature of a liberating social order (Horsley, 2001) referred to in Mark and Luke as the 'Kingdom of God' and in Matthew as the 'Kingdom of the Heavens' (Hart, 2017). Faithful to ancient Jewish prophetic traditions of social-economic critique, eschatological hope and the pronouncement of judgement against systems of oppression and injustice, this (anti)kingdom was to be inaugurated and lived through a praxis of radical love ${ }^{1}$, healing, non-violence, shared abundance, spiritual renewal, community reconciliation and perhaps most transformatively of all in the context of the first-century Palestinian economy - debt-forgiveness (Myers, 2008; Horsley, 2012, 2015). All this was, quite understandably, cast as 'good news' for the poor and marginalised, whose debt-haunted lives were dominated by the constant, demoralising tyranny of actual or threatened destitution (Van Eck, 2010). Equally understandably, it would have been received rather more like bad news by those whose wealth, power and social status were derived from, and could survive only by maintaining, this very same tyranny. And, as we know all too well from the dismal record of human history, to challenge iniquitous economic structures and practices, to threaten to disrupt the orderly administration of empire, is to risk inviting the full fury of institutional power (Horsley, 2013). Along with numerous other biblical scholars and theologians, Diana L. Hayes (2000) points out that such a reading of the Gospels has often proven straightforward enough to oppressed peoples. The colonisation of these texts has never been, after all, an entirely successful ideological enterprise.

To return to the parables, for Edward Schillebeeckx (1987, p.29) it was precisely the utopian/eschatological (and as such ultimately indescribable) nature of 'the Kingdom' that necessitated the use of parabolic and metaphorical modes of communication, able to reach imaginatively beyond the 'impoverishing sharpness' of more direct and definitional modes. In this way, the parables worked to dislodge and destabilise 'the entrenched domination of worldly logic and power' (Putt, 2017, p.50) - creating in the space thus opened opportunities to think against and beyond this logic. As Peter Rule (2017, p.2)

\footnotetext{
${ }^{1}$ Not to be confused with a perfectly laudable, if comparatively anodyne, 'concern for the wellbeing of others', this love was an altogether more militant and immoderate affair, entailing an unyielding solidarity with the oppressed, even at the risk of (indeed, very likely to result in) a violent death at the hands of the authorities.
} 
explains, a related feature of these stories is their refusal to admit any simple, singlemeaning interpretations:

... [T] he pedagogical purpose of [Jesus'] parables... [is] to tease the minds of listeners into active thought. The purpose thus differs from more straightforward instructional genres such as commandments, rules and procedures. It involves provoking a playful but serious labour of interpretation, an opening to possibilities of meaning, rather than indicating a single denotation.

Now, I realise that I have strayed some distance from the terrain of contemporary higher education, so I will stop here and stray no further. I hope, though, that these introductory sections have helped to establish the parable's ancient as well as modern criticalpedagogical credentials.

\section{But enough about those guys...}

I trust it goes without saying, but I will say it just in case: the stories I have been working on do not serve anything like the kind of revolutionary aspirations narrated and dramatised in the Synoptic Gospels! Nor am I so utterly lacking in self-awareness as to claim any kind of creative or intellectual lineage with the likes of Brecht, Kafka or Benjamin. What I am doing is borrowing certain narrative and stylistic devices in order to further the far more modest aims of encouraging critical and reflective orientations towards certain values and practices in my own area of tertiary education. Writing specifically of the potential for parables to help enable this process within the context of educational practice, Bullough explains: 'Moving from concrete and commonplace events and experiences, parables... [require that] a troubling imaginative choice be made that reveals who and what they [the readers/hearers] are, what they value, and where they stand' (2010, p.154). It is just this kind of 'troubling imaginative choice' that the parables I have been working on are attempting to prompt readers into considering. To what end? Well, if pressed to reveal a broader agenda behind all of this, I would say that I am attempting to work with Jan McArthur's notion that the role of higher education in promoting social justice is sustained, at least in part, by its 'providing a place, a sanctuary, for thinking outside the current reality, which is simultaneously anchored in that reality.' (2013, p.109). 


\section{'In the parable, you've lost.' (Kafka, 2017 [1922], p.181): How (and how not) to read a parable.}

During the conference workshop in which I presented the parables below, I offered a brief set of recommendations entitled, 'How (and how not) to read a parable'. Here, I have taken the more mischievous step of adapting these into a set of anti-guidelines (perhaps they might themselves be read as a parable on the provision of such guidelines?):

1) Every parable carries a clear and unambiguous message, and so it is very much your job to figure out what this message is - preferably before anybody else does. As a contest of how clever, and how 'in on the author's intentions' you are, it is crucial to 'solve' the parable and announce your solution as the correct one, over and against any erroneous interpretations you hear from others.

2) Parables often present certain tensions and conflicts and, as such, it is absolutely vital you take sides - quickly and without compromise. Bearing in mind the previous recommendation, every parable also contains a correct side. So, and just to add to the stress of it all, you will have to think very carefully as well as very quickly. Just imagine the shame and humiliation of discovering you have chosen the wrong side!

3) If you detect the allegorical or metaphorical at work in a parable, then the next step is to nail precisely, and indisputably, what it is an allegory or metaphor for. Figure that out and, provided you've followed the previous two steps, you will be the undisputed winner - a true master of parable interpretation.

In all seriousness, though, here are some questions that, I hope, will prove genuinely helpful in supporting engagement:

1) What questions or issues does the story draw your attention to?

2) What tensions or contradictions does the story seek to open up and make more visible?

3) What assumptions/values/practices etc. does the story seem to invite (re)examination of? 
4) Who are the characters? What relations, including power relations, might be at work between them?

5) Do you find yourself drawn to/repelled by any of the characters and what they have to say? If so, why do you think this is?

6) What assumptions might you be bringing to the story and its characters, and where might these come from? How might these shape your responses to the story?

In devising these questions, I have the generous advice and practical help of my University of Leicester colleague, Dr Alexandra Patel, to thank.

Here, then, are a trio of parables discussed during the workshop. (At this point, I really must express my immense gratitude to those who attended the workshop. I could not have wished for a more generous, willing and insightful group of people with whom to share these stories in public for the first time.) I would encourage collaborative discussion, wherever possible, as this should allow a greater diversity of perspectives to be shared and so provide for a more interesting interpretive experience.

\section{1) The unconventional marker}

Once, during a staff development session entitled 'Improving assessment and feedback', discussion turned to the allocation of marks. (As is the fashion these days, it was one of those sessions where periodic injunctions to talk out loud were deemed to be an indispensable aid to the learning process.) People spoke of how challenging they often found marking - of how much care they felt they needed to take to ensure that it was fair, consistent, transparent, and above all based on 'relevant and well-designed criteria and rubrics'.

'Oh, I don't let any such concerns interfere with my marking' said one.

'Really?' said another. 'What do you do, then?'

'I just give everyone the same pre-allocated mark. Indeed, I've started to release all the marks at the beginning of the module so as to avoid any further anxiety or confusion.' Well, you can imagine the response.

Someone said, 'But...but... how will they know if they've done a good job or not?' 'Time permitting, l'll tell them. Indeed, the time freed up by not worrying about what mark to give means I'm more likely to be able to tell them. To be honest, though, in my 
experience they usually already know perfectly well themselves if they've done a decent job or not.'

Another said, 'But... then....I mean... how... how on earth can you justify doing this? Your students are all different, surely? You're not seriously telling me they've ever actually, literally, all produced work of identical quality?'

'Oh, you're absolutely right about the whole difference thing. Couldn't agree more. I'd never do violence to the diversity of my students by awarding them anything other than identical marks. Differential marks, in such circumstances, would be horribly unjust.

Everyone is different, after all.'

'And these identical marks you award, do they tend to be higher or lower?'

'High marks, of course, always the higher marks. What good are lower marks to anyone? Don't forget, they'll soon be leaving behind this game of ours to go and play the game of 'getting-a-job'. Imagine sending them out into that brutal charade with low marks next to their names? I couldn't live with myself!'

A few days after the workshop, this unconventional marker received an email inviting them to meet with someone who went by the title, 'Dean of Quality'.

\section{2) Belonging Week}

The university was very proud - excited, in fact - to be hosting its inaugural Belonging Week. A series of events, all with a focus on fostering a 'greater sense of belonging', were taking place. These included: a Festival of Belonging; a Belonging Question Time, featuring a panel drawn from the senior leadership team; and, taking pride of place in the centre of campus, a great big bouncy Castle of Belonging which, owing to persistent heavy rainfall and consequent health and safety concerns, had thus far proved unusable. Every academic department had nominated a Belonging Champion, large photographs of whom were displayed on TV screens and on giant Belonging Boards around the campus. Students could find out more about events and activities either by downloading the university's I-Belong app, or by visiting one of the numerous pop-up Belonging Booths, staffed by volunteer Belonging Buddies.

During the week, all first year undergraduate students were invited meet with their personal tutor for a Belonging Conversation. During one such conversation a student explained: 'I can't say I feel like I belong here at all, to be honest.'

'Oh,' said the tutor, 'Why is that?' 
'Well, it seems that to belong here, to really belong here, you just have to kind of be a certain way. I'm not like that and I never will be, so I guess I'll never belong.'

The personal tutor glanced nervously down at the 'Guidance Notes and Suggested Questions' they had been issued at a recent Belonging Briefing they had been mandated to attend. After a few moments fruitless scanning they finally asked, rather mechanically: 'Are you aware of the full range services in place to support students' mental health and wellbeing?'

'Mind you' the student continued, ignoring the tutor's question, entirely. 'It could be worse, I suppose.'

'Really? How so?' asked the tutor.

'Well, I could be more like one of those who do belong.'

\section{3) The manager who despised quick wins}

Once there was a manager - a very melancholy, dejected-looking manager. The reason for this dismal countenance? A profound and impossible-to-conceal distaste for 'quick wins'. And yet quick wins were all anyone would ever propose. Indeed, the manager was convinced, quick wins were all that anyone was capable of even conceiving. Whatever the problem, whatever its scale, in they would rush, proudly proclaiming their latest 'good-togo' proposals for quick wins.

Then one day, at a hastily convened meeting to discuss the latest institutional panic to have somehow found its way to their section, a newcomer (they had only been in post for a couple of weeks, during which time they had uttered not a single word the others could recall) said: 'I've an idea about what we might do.'

'Oh good' said a colleague. 'Something we can do straight away? Something guaranteed to bear fruit in the short-term?'

'Oh no,' replied the newcomer, 'nothing like that. I can see this taking years, maybe even decades.'

'Decades?' said the colleague, 'Decades!?'

The others in the room looked stunned and embarrassed. None dared look at the newcomer, or at each other for that matter.

'Ok, ok' said another at last. 'Let's not judge until we've heard more.'

Although privately as horrified as the others, this member of the team - being of a kindly, nurturing disposition - was nonetheless anxious to ensure the newcomer did not suffer the 
kind of public embarrassment that might dissuade them from venturing ideas for quicker wins in future. Turning a benevolent gaze towards the newcomer, they went on: 'You must feel very confident in this long-term solution of yours delivering the goods? You're sure it will work, I trust?'

'Oh, I very much doubt that' said the newcomer. 'I can't see it working at all, to be honest. Indeed, I'd be dismayed in the extreme if I thought for one moment it was in any danger of, to use your phrase, "delivering the goods"'.

At this, the manager coughed gently (more for effect than of necessity), smiled publicly for the first time anyone could remember, and said: 'Well, what are you all waiting for? This slow loss [how the manager savoured these words!] won't implement itself.'

'Well, actually...' began the newcomer, rather awkwardly it must be said. 'I mean, I don't want to cause...'

The manager's smile broadened as they raised their hand to interrupt.

'That's alright, you needn't say any more. I quite understand. My mistake, and I'm sorry for it, I truly am. I, of all people, should have known better!'

With that, the manager got up to leave the room - not only smiling now but chuckling, too, with the air of one for whom cheerful contentment with the world was their most natural and common disposition.

\section{In conclusion}

Where next with any of this? As I explained to those who attended the workshop, I would like to present these and other parables to a wider cross-section of educational practitioners so as to explore in greater depth their use and effectiveness (or otherwise!). I would also like to encourage and support others in experimenting with this form in their own professional contexts. I realise I could go further along these lines at this point. I could summarise and distil the previous sections; pull together various strands into some kind of closing statement; perhaps sketch out some further questions for future exploration. But I cannot help feeling that, given all I have said about parables, this would be a rather unfaithful move on my part - more a betrayal than a 'summing up' of what has gone before. So instead, I will offer one more parable - a story that owes more than a minor debt to the one with which the article opened... 


\section{Epilogue}

Once there was a learning developer who, having had the idea of writing some parables, decided to take these to a conference workshop to see what colleagues thought.

Before being allowed to view the parables, workshop participants were made to endure a protracted history of the parable as a form. Great pains were taken, during this tiresome exposition, to point out that the parable was - in the words of contemporary theologian and fellow-parablist, Peter Rollins - 'not reducible to some clear, singular, scientific formula but rather...[open to] a multitude of commentaries.' (Mindful of the scholarly sensitivities of the audience, the learning developer was careful to add that this quotation was taken from a book published in the year 2006, and could be found on pages sixteen and seventeen.) Next, the participants were issued with a set of questions to accompany their engagement with the parables. These had been designed, it was announced, 'to foreclose the possibility of closure' - a phrase the learning developer uttered with a certain flourish, suggesting they felt rather pleased with themselves for having coined it.

When, at long last, participants got to work with the parables, however, something strange and rather unexpected took place. Responding to story after story, they kept arriving, with minimal fuss or deliberation, at precisely the same interpretation. Worse, these identical interpretations were all couched in definitive terms - as if any other interpretation than the one they had all arrived at was unthinkable. There were lots of 'Oh, I see what it's saying' and 'Yes, my view, entirely, it's clearly encouraging us to...' and 'Wait, I think I've got it!' and so on. Throughout, the learning developer tried their best to intervene, to suggest alternative possible readings. But these were all calmly rejected by the participants. If anything, they seemed to serve merely to strengthen the unanimity of opinion.

'Why are you doing this?' the learning developer asked at last. 'We've been through it so many times. You've all seen how parables are designed to work and yet you keep on arriving at the single meaning, the one message you've all agreed the parables must be instructing you to take away. You don't get it at all, do you? I'm disappointed in you, to be honest.'

After a brief silence, one of the participants smiled and said: 'I suppose we must seem to you like characters in one of your stories.' 
With this, the participants burst into raucous and, to the learning developer's ears at least, rather deranged laughter. One of them began to sing (to the tune of the chorus of The Beatles' Yellow Submarine): "Weee ah - gree on what all the stories mean / all the stories mean / all the stories mean..." Soon, the rest of them joined in, and it wasn't long before other conference delegates, from other sessions taking place in tandem, arrived to find out what all the commotion was about. Without really understanding the source or context for the laughter or the singing, they all joined in nonetheless - this seeming like the most appropriate and participatory thing to do in the circumstances. (One of the key themes of that year's conference was, after all, the importance of 'participatory learning'.) There was only one person who remained silent all this time, and that was the learning developer, who really hadn't a clue what was going on.

\section{References}

Adichie, C.N. (2006) Half of a Yellow Sun. London: $4^{\text {th }}$ Estate.

Bullough, R.V. Jr. (2010) 'Parables, Storytelling and Teacher Education', Journal of Teacher Education, 61(1-2), pp. 153-160.

Benjamin, W. (2008 [1934]) 'Franz Kafka: On the Tenth Anniversary of His Death', pp. 51 91, in Benjamin, W. and Underwood, J.A. (Translator) The Work of Art in the Age of Mechanical Reproduction. London: Penguin Books.

Carter, W. (2006) The Roman Empire and The New Testament: An Essential Guide, Nashville (USA): Abingdon Press.

Champion, J. (1981) 'The parable as an ancient and modern form', Journal of Literature \& Theology, 3(1), pp.16-37.

Cone, J.H. (2018 [1970]) A Black Theology of Liberation, New York (USA): Orbis Books. 
Crossan, J.D. (1976) Raid on the Articulate: Comic Eschatology in Jesus and Borges. Oregon (USA): Wipf and Stock Publishers.

Eagleton, T. (2009) Reason, Faith and Revolution: Reflections on the God Debate, New Haven (USA): Yale University Press.

Fischer, G. (2008) 'Good Building': Bertolt Brecht's Utopian Historical Optimism at the End of World War II', Cultural Studies Review, 14(1), pp. 137-146.

Hart, D.B. (2017) The New Testament: A translation. New Haven (USA): Yale University Press.

Hayes, D.L. (2000) 'James Cone's Hermeneutic of Language and Black Theology', Theological Studies, 66, pp. 609-631.

Herzog, W.R. (1994) Parables as subversive speech: Jesus as pedagogue of the oppressed. Westminster (USA): John Knox Press.

Horsley, R.A. (2001) Hearing the Whole Story: The Politics of Plot in Mark's Gospel. Westminster (USA): John Knox Press.

Horsley, R.A. (2012) The Prophet Jesus and the Renewal of Israel: Moving beyond a Diversionary Debate. Michigan (USA): Wm. B. Eerdmans Publishing Co.

Horsley, R.A. (2013) Jesus and the Politics of Roman Palestine. USA: University of South Carolina Press.

Horsley, R.A. (2015) 'You Shall Not Bow Down and Serve Them: Economic Justice in the Bible', Interpretation: A Journal of Bible and Theology, 69(4) pp.415-431.

Kafka, F. and Hofmann, M. (Translator) (2017 [1931]) The Burrow. London: Penguin.

Kierkegaard, S. (1978) Parables of Kierkegaard, New Jersey (USA): Princeton University Press. 
McArthur, J. (2013) Rethinking Knowledge within Higher Education: Adorno and Social Justice. London (England): Bloomsbury.

Myers, C. (2008) Binding the Strongman: A Political Reading of Mark's Story of Jesus. New York (USA): Orbis Books.

Putt, B.K. (2017) 'A Poetics of Parable and the 'Basileic Reduction': Ricoeurean Reflections on Kevin Hart's Kingdoms of God', Sophia, 56(1), pp.45-58.

Rollins, P. (2006) How (Not) To Speak of God. Massachusetts (USA): Paraclete Press.

Roy, A. (2015) Capitalism: A ghost story. London: Verso.

Rule, P.N. (2017) 'The Pedagogy of Jesus in the Parable of the Good Samaritan: a diacognitive analysis', HTS Theological Studies, 73(3), pp. 1-8.

Schillebeeckx, E. (1987) Jesus in Our Western Culture: Mysticism, Ethics and Politics. London: SCM Press Ltd.

Schottroff, L. (2009) 'The Kingdom of God is not like you were made to believe: reading parables in the context of Germany and Western Europe', pp. 169-179, in Botta, A.F. and Andiach, P.R. (eds) The Bible and the Hermeneutics of Liberation. Society of Biblical Literature.

Thompson, P.L. (n.d.) 'Half of a Yellow Sun: Adichie's Historical Parable of Race, Class, and Politics', radicalscholarship.wordpress.com. Available at: https://radicalscholarship.wordpress.com/2017/01/18/half-of-a-yellow-sun-adichieshistorical-parable-of-race-class-and-politics/ Accessed 1.12.19

Van Eck, E. (2010) 'A prophet of old: Jesus the 'public theologian", HTS Theological Studies, 66(1), pp.1-10. 


\section{Author Details}

Steve Rooney is Head of Learning Development at the Leicester Learning Institute, University of Leicester. He has been a member of the ALDinHE Steering Group and is currently a member of the Conference and Research and Development Working Groups 